\title{
Evidence of mast cell activation and leukotriene release after mannitol inhalation
}

\author{
J.D. Brannan*, M. Gulliksson\#, S.D. Anderson*, N. Chew", M. Kumlin\#
}

Evidence of mast cell activation and leukotriene release after mannitol inhalation. J.D. Brannan, M. Gulliksson, S.D. Anderson, N. Chew, M. Kumlin. (C) ERS Journals Ltd 2003.

ABSTRACT: The aim of this study was to investigate if mannitol inhalation, as a model of exercise-induced bronchoconstriction (EIB), causes mast cell activation and release of mediators of bronchoconstriction.

Urinary excretion of previously identified mediators of EIB was investigated in association with mannitol-induced bronchoconstriction. Twelve asthmatic and nine nonasthmatic subjects inhaled mannitol and urine was collected 60 min before and for $90 \mathrm{~min}$ after challenge. The urinary concentrations of leukotriene (LT)E $\mathbf{E}_{4}$,

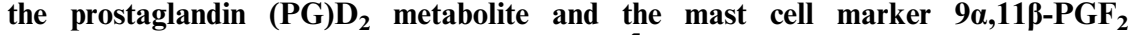
were measured by enzyme immunoassay. $\mathrm{N}^{\tau}$-methylhistamine was measured by radioimmunoassay.

In asthmatic subjects, inhalation of a mean \pm SEM dose of $272 \pm 56 \mathrm{mg}$ mannitol induced a reduction in forced expiratory volume in one second (FEV1) of 34.5 $\pm 2.1 \%$. This was associated with increases in urinary $9 \alpha, 11 \beta-P_{2} F_{2}(91.9 \pm 8.2$ versus $66.9 \pm$ $6.6 \mathrm{ng} \cdot \mathrm{mmol}$ creatinine ${ }^{-1}$, peak versus baseline) and $\mathrm{LTE}_{4}(51.3 \pm 7.5$ versus $32.9 \pm 4.7)$. In nonasthmatic subjects, the reduction in FEV1 was $1.0 \pm 0.5 \%$ after inhaling $635 \mathrm{mg}$ of mannitol. Although smaller than in the asthmatics, significant increases of urinary

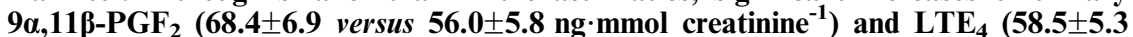
versus $43.0 \pm 3.3 \mathrm{ng} \cdot \mathrm{mmol}$ creatinine $^{-1}$ ) were observed in the nonasthmatic subjects. There was also a small increase in urinary excretion of $\mathbf{N}^{\tau}$-methylhistamine in the nonasthmatics, but not in the asthmatics.

The increased urinary levels of $9 \alpha, 11 \beta$-prostaglandin $F_{2}$ support mast cell activation with release of mediators following inhalation of mannitol. Increased bronchial responsiveness to the released mediators could explain the exclusive bronchoconstriction in asthmatic subjects.

Eur Respir J 2003; 22: 491-496.
*Dept of Respiratory Medicine, Royal Prince Alfred Hospital, Camperdown, Australia. ${ }^{\#}$ Div for Experimental Asthma \& Allergy Research, The National Institute of Environmental Medicine, Karolinska Institutet, Stockholm, Sweden. "Dept of Pharmacy, University of Sydney, Sydney, Australia.

Correspondence: S.D. Anderson, Dept of Respiratory Medicine, E11S, Royal Prince Alfred Hospital, Missenden Road, Camperdown, Australia.

Fax: 61295158196

E-mail: sandya@mail.med.usyd.edu.au

Keywords: Bronchial provocation, leukotriene $\mathrm{E}_{4}$, mannitol, $\mathrm{N}^{\tau}$-methylhistamine, $9 \alpha, 11 \beta-$ prostaglandin $\mathrm{F}_{2}$, urinary mediators

Received: January 302003

Accepted after revision: April 92003

This study was supported by the National Health and Medical Research Council of Australia (J.D. Brannan), the Swedish Medical Research Council (12754, 13047, 9072), the Swedish Society for Health Care and Allergy Research (Vårdalstiftelsen), the Swedish Heart Lung Foundation, the Swedish Asthma and Allergy Research Foundation and Karolinska Institutet.
The mechanism whereby exercise causes the airways to narrow is by the osmotic and thermal consequences of evaporative water loss in humidifying the inspired air [1]. Release of mediators from inflammatory cells, and the mast cell in particular, in exercise-induced bronchoconstriction (EIB) has been inferred from studies showing a modification of the airway response by specific mediator antagonists [2] or the mast cell active drugs, such as cromoglycate and nedocromil [3].

Direct evidence for mediator release following exercise in asthmatics has been obtained by an increase in the urinary levels of the mast cell marker $9 \alpha, 11 \beta$-prostaglandin $(\mathrm{PG}) \mathrm{F}_{2}$, a metabolite of $\mathrm{PGD}_{2}$, and leukotriene (LT) $\mathrm{E}_{4}$ in association with EIB [4-7].

A positive response to mannitol identifies asthmatics with EIB $[8,9]$ and there are no significant airway responses to mannitol in healthy nonasthmatics [10]. Inhaled mannitol is thought to cause airways to narrow in asthmatics by a similar mechanism to exercise, that is by increasing the osmolarity of the airway surface liquid [8]. It is known that mediator secretion from mast cells, basophils and human lung fragments is triggered by increased osmolarity [11, 12] and this release is inhibited with nedocromil sodium [13]. As with EIB, the airway response to mannitol may be modified by specific mediator antagonists [14]. However, there is no direct evidence for mediator release from mast cells or other cells occurring in response to inhaled mannitol.

The present study was undertaken to investigate if mannitol-induced bronchoconstriction in asthmatics was associated with mast cell activation and the release of mediators of bronchoconstriction, analogous to that observed in asthmatics with EIB. To this end the urinary levels of the $\mathrm{PGD}_{2}$ metabolite $9 \alpha, 11 \beta-\mathrm{PGF}_{2}$ were measured before and after a mannitol challenge in atopic asthmatics and in nonasthmatic nonatopic subjects who served as controls. The urinary excretion of $\mathrm{N}^{\tau}$-methylhistamine was also measured, as well as $\mathrm{LTE}_{4}$, in view of pharmacological data supporting the role for cysteinyl-LTs and histamine in the bronchoconstriction following the inhalation of mannitol [14].

\section{Methods}

\section{Subjects}

Twelve atopic asthmatics (eight males, four females, aged 25-42 yrs) and nine nonatopic nonasthmatics (five males, four 
females, aged 22-33 yrs), all nonsmokers without any chest infection in the 4-week period preceding the challenge, were included in the study (table 1). Asthmatic subjects were required to have a baseline forced expiratory volume in one second (FEV1) $>70 \%$ predicted while nonasthmatic subjects were required to have normal spirometry (all parameters) [15]. To enter the study, it was a requirement for the asthmatic subjects that the reduction in FEV1 was sustained at $\geqslant 15 \%$ of baseline FEV1 for the $30 \mathrm{~min}$ following the challenge. Shortacting $\beta_{2}$-agonists were withheld for $6 \mathrm{~h}$ and nedocromil sodium or sodium cromoglycate was withheld for $48 \mathrm{~h}$. Inhaled corticosteroids were not used on the day of the study. No subject was taking long-acting $\beta_{2}$-agonists or antihistamines. All subjects were required to abstain from alcohol, caffeine and niacin-containing drinks and foods from 20:00 $\mathrm{h}$ the evening before the study and no vigorous exercise was permitted on the study day. The Central Sydney Area Health Service Ethics Committee approved the studies (Protocol No. X99-0089) and all subjects signed a consent form. The study was performed under the Clinical Trials Notification Scheme of the Therapeutic Goods Administration of Australia (CTN\# 1999/150).

\section{Study design}

At commencement, two baseline urine samples were collected $1 \mathrm{~h}$ apart, at $60 \mathrm{~min}$ before and immediately before the start of mannitol challenge, and spirometry measurements were performed. The FEV1 was used as the index of change in airway calibre (Microlab 3300 spirometer; Micro Medical, Kent, UK). A mannitol challenge was performed by progressively increasing the doses, as described previously [10]. Briefly, the dose protocol consisted of 0 (empty capsule acting as a placebo), 5, 10, 20, 40, 80, 160, 160 and $160 \mathrm{mg}$ mannitol. The $80-$ and $160-\mathrm{mg}$ doses were given in multiples of $40-\mathrm{mg}$ capsules. Three FEV1 manoeuvres were performed $60 \mathrm{~s}$ after each dose and the highest FEV1 measurement was recorded. The FEV1 value measured after the $0 \mathrm{mg}$ capsule was used to calculate the per cent decrease in FEV1 in response to the mannitol challenge. If the subject had a decrease of $\geqslant 10 \%$ the dose producing this was repeated for safety reasons. The challenge was completed in asthmatic subjects when $\mathrm{a} \geqslant 25 \%$ reduction in FEV1 was documented or, for the nonasthmatic subjects, when the maximum cumulative dose of mannitol was administered $(635 \mathrm{mg})$. The provoking dose required to cause a $15 \%$ fall in FEV1 (PD15) for mannitol, an index of airway hyperresponsiveness, was calculated from the relationship between the per cent fall in FEV1 and the cumulative dose of mannitol required to provoke this fall. Airway recovery following mannitol was spontaneous and FEV1 was measured at 5 min and then at 10min intervals for up to 90 min after the start of the challenge.

Additional urine samples were collected at 30,60 and 90 min after the challenge and all samples were stored without addition of preservatives at $-80^{\circ} \mathrm{C}$.

\section{Mediator analyses}

Enzyme immunoassay analyses of $9 \alpha, 11 \beta-\mathrm{PGF}_{2}$ and $\mathrm{LTE}_{4}$ were performed in unextracted urine samples with rabbit polyclonal antisera and acetylcholinesterase-linked tracers (Cayman Chemical Company, Ann Arbor, MI, USA) essentially as described previously [16]. However, in the present study, a different antibody was used for analysis of $\mathrm{LTE}_{4}$, which cross-reacted with $\mathrm{LTE}_{4}$ to $67 \%$ and with $\mathrm{LTC}_{4}$ and $\mathrm{LTD}_{4}$ to $100 \%$. Measurement of urinary $\mathrm{N}^{\tau}$-methylhistamine was performed with a commercial double-antibody radioimmunoassay (Pharmacia AB, Uppsala, Sweden). Creatinine

Table 1. - Anthropometric data, daily medication, dose of inhaled steroids, forced expiratory volume in one second (FEV1) \% predicted, \% reduction in FEV 1 , provoking dose of mannitol to cause a 15\% fall in FEV 1 (PD15) and total dose of mannitol for asthmatic and nonasthmatic subjects

\begin{tabular}{|c|c|c|c|c|c|c|c|c|}
\hline Subject no. & Age yrs & Sex & Medication & $\begin{array}{l}\text { Steroid } \\
\mu \mathrm{g} \cdot \mathrm{day}^{-1}\end{array}$ & $\begin{array}{c}\text { Baseline } \\
\text { FEV1 \% pred }\end{array}$ & $\begin{array}{l}\% \text { Reduction } \\
\text { FEV } 1\end{array}$ & PD15 mg & $\begin{array}{c}\text { Total dose } \\
\mathrm{mg}\end{array}$ \\
\hline A1 & 25 & $\mathrm{~F}$ & S & & 88 & 47.3 & 22.0 & 75 \\
\hline A2 & 29 & M & $\mathrm{S}$ & & 94 & 27.6 & 300.0 & 635 \\
\hline A3 & 42 & $\mathrm{~F}$ & S, Bud & 2400 & 98 & 36.2 & 36.3 & 155 \\
\hline A4 & 20 & $\mathrm{~F}$ & $\mathrm{~S}, \mathrm{Fl}$ & 500 & 103 & 35.8 & 148.9 & 315 \\
\hline A5 & 29 & $\mathrm{~F}$ & $\mathrm{~S}, \mathrm{Fl}, \mathrm{SCG}$ & 1000 & 101 & 27.7 & 85.8 & 315 \\
\hline A6 & 41 & $\mathrm{~F}$ & Bud & 800 & 90 & 27.5 & 244.4 & 635 \\
\hline A7 & 30 & $\mathrm{~F}$ & $\mathrm{~S}, \mathrm{Fl}$ & 500 & 86 & 27.6 & 54.6 & 155 \\
\hline A8 & 31 & M & $\mathrm{S}$ & & 104 & 34.7 & 159.4 & 315 \\
\hline A9 & 26 & M & S, Bud & 1600 & 78 & 27.3 & 72.4 & 155 \\
\hline A10 & 36 & $\mathrm{~F}$ & $\mathrm{~S}$ & & 109 & 37 & 48.1 & 155 \\
\hline A11 & 31 & M & S, Bud & 1200 & 83 & 41.2 & 111.7 & 315 \\
\hline A12 & 27 & $\mathrm{~F}$ & $\mathrm{~S}$ & & 90 & 44.5 & 9.2 & 35 \\
\hline Mean \pm SEM & & & & & $93.7 \pm 2.7$ & $34.5 \pm 2.1$ & 73.1 & $272 \pm 56$ \\
\hline $95 \%$ CI & & & & & & & $(38.4-139)$ & \\
\hline N1 & 30 & M & & & 115 & 0.0 & & 635 \\
\hline N2 & 31 & $\mathrm{M}$ & & & 119 & 0.4 & & 635 \\
\hline N3 & 33 & $\mathrm{M}$ & & & 111 & 3.3 & & 635 \\
\hline N4 & 22 & $\mathrm{~F}$ & & & 114 & 1.0 & & 635 \\
\hline N5 & 25 & $\mathrm{~F}$ & & & 116 & 0.0 & & 635 \\
\hline N6 & 22 & $\mathrm{~F}$ & & & 96 & 0.0 & & 635 \\
\hline N7 & 27 & M & & & 89 & 0.0 & & 635 \\
\hline N8 & 29 & $\mathrm{~F}$ & & & 104 & 0.8 & & 635 \\
\hline N9 & 33 & $\mathrm{~F}$ & & & 102 & 3.6 & & 635 \\
\hline Mean \pm SEM & & & & & $107.3 \pm 3.4$ & $1.0 \pm 0.5$ & & 635 \\
\hline
\end{tabular}

$\%$ pred: \% predicted; A: asthmatic; N: nonasthmatic; M: male; F: female; S: salbutamol; BUD: budesonide; Fl: fluticasone; SCG: sodium cromoglycate. 
analyses were performed with a colorimetric assay (Sigma, St Louis, MO, USA).

\section{Statistical analysis}

All values are expressed as mean \pm SEM unless otherwise stated. Mean values before and the peak value for concentration of urinary mediators ( $\mathrm{ng}$ or $\mu \mathrm{g} \cdot \mathrm{mmol}$ creatinine $^{-1}$ ) after challenge were compared by using the Student's t-test and were considered significantly different if the p-value was $<0.05$. Values were found to be normally distributed.

\section{Results}

\section{Asthmatic subjects}

All asthmatic subjects achieved the required sustained airway response following inhaled mannitol with a $34.5 \pm 2.1 \%$ reduction in FEV1 following a mean cumulative dose of mannitol of $272 \pm 56 \mathrm{mg}$ (fig. 1, table 1). The airway response was associated with increases in the urinary excretion of $9 \alpha, 11 \beta-\mathrm{PGF}_{2}$ in all subjects (fig. $2 \mathrm{a}$ ), calculated as peak value versus mean of two baseline samples, with a mean significant increase $\left(91.9 \pm 8.2\right.$ versus $66.9 \pm 6.6 \mathrm{ng} \cdot \mathrm{mmol}$ creatinine $^{-1}$; $\mathrm{p}<0.001)$. The levels of urinary $9 \alpha, 11 \beta-\mathrm{PGF}_{2}$ peaked at 30 min following the mannitol challenge, with levels back to baseline at 90 min (fig. 3a).

There was also a significant increase in the urinary levels of $\mathrm{LTE}_{4}\left(51.3 \pm 7.5\right.$ versus $32.9 \pm 4.7 \mathrm{ng} \cdot \mathrm{mmol}$ creatinine $\left.{ }^{-1} ; \mathrm{p}<0.05\right)$ (fig. 2b). The post mannitol levels of $\mathrm{LTE}_{4}$ were sustained at 30-90 min, with no significant decline (fig. 3b).

In contrast, there was no detectable increase in the urinary excretion of $\mathrm{N}^{\tau}$-methylhistamine in response to the mannitol challenge $\left(20.9 \pm 2.8\right.$ versus $18.2 \pm 2.1 \mu \mathrm{g} \cdot \mathrm{mmol}$ creatinine $^{-1}$; $\mathrm{p}=0.1$ ) (fig. 2c).

\section{Nonasthmatic subjects}

In nonasthmatic subjects there was no significant airway response to inhaled mannitol with a $1.0 \pm 0.5 \%$ reduction in

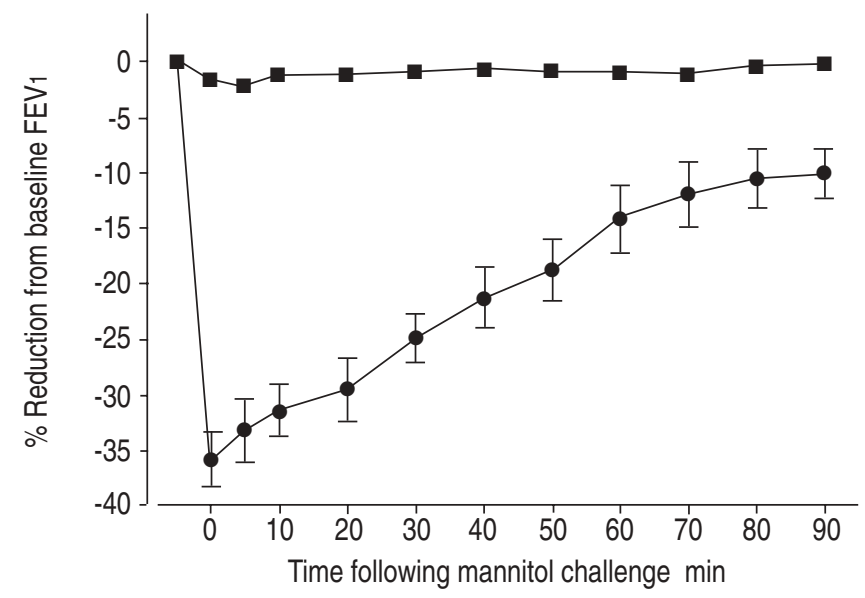

Fig. 1.- The percentage reduction in forced expiratory volume in one second $(\mathrm{FEV})$ from baseline following a mannitol challenge and spontaneous recovery in FEV1 in asthmatic $(0: n=12)$ and nonasthmatic ( $\boldsymbol{\square}: \mathrm{n}=9)$ subjects. The mean \pm SEM cumulative dose of mannitol delivered to the asthmatic subjects was significantly lower $(272 \pm 56 \mathrm{mg})$ compared with nonasthmatic subjects $(635 \mathrm{mg})$ $(\mathrm{p}<0.001)$.
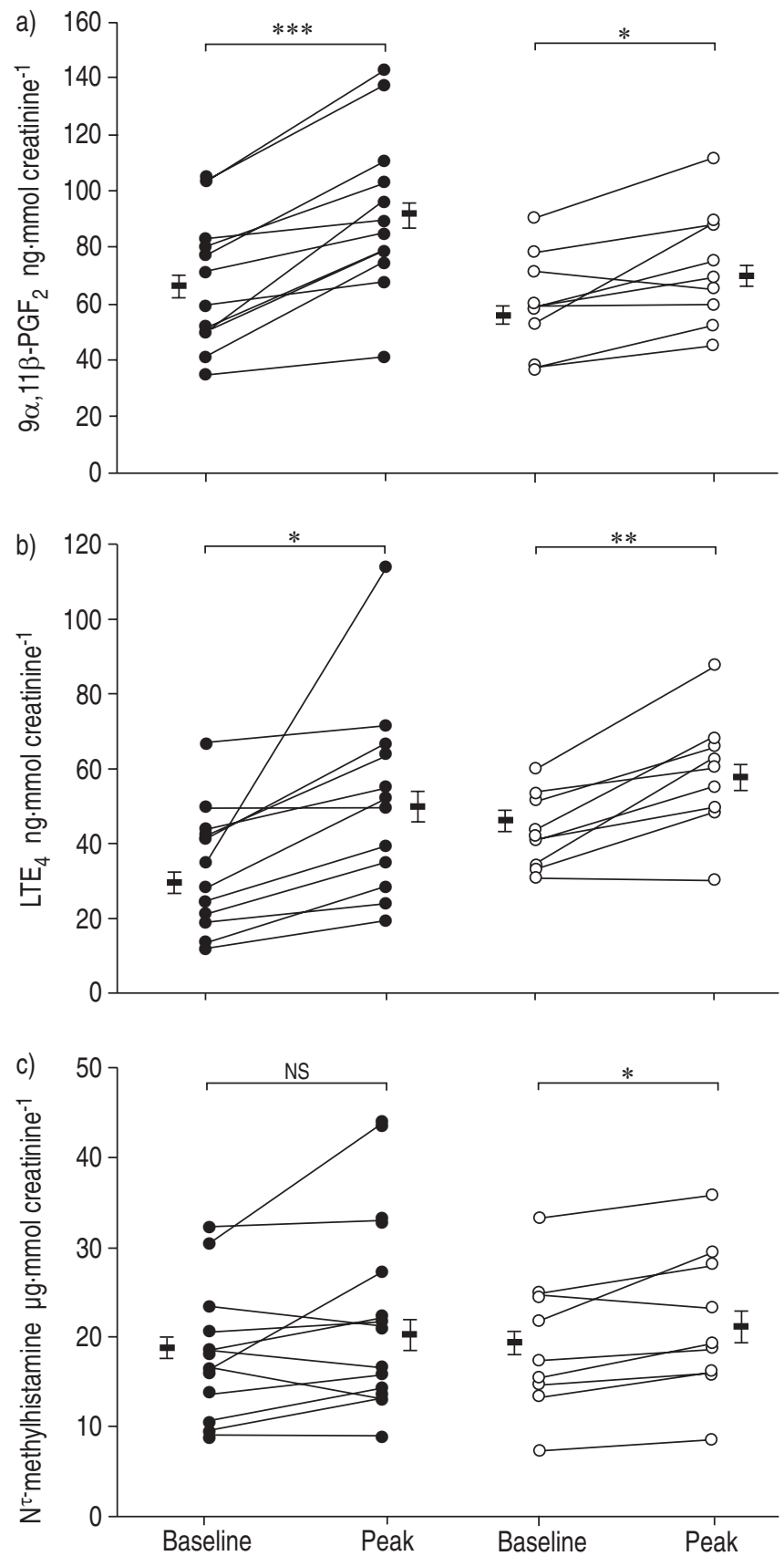

Fig. 2.-a) $9 \alpha$,11 -Prostaglandin ( $\mathrm{PG}) \mathrm{F}_{2}$, b) leukotriene (LT)E $\mathrm{E}_{4}$ and c) $\mathrm{N}^{\tau}$-methylhistamine in urine measured initially as the mean of the two baseline samples and then as the peak values measured over the 90 min collection period after the mannitol challenge in asthmatic (O) and nonasthmatic $(\bigcirc)$ subjects. Data are presented as mean \pm SEM. NS: nonsignificant. *: $\mathrm{p}<0.05 ; * *: \mathrm{p}<0.01 ; * * *: \mathrm{p}<0.001$.

FEV1 following challenge with the maximum cumulative dose of $635 \mathrm{mg}$ (fig. 1). This dose was significantly greater than the cumulative dose delivered to the asthmatic subjects $(\mathrm{p}<0.001)$. However, calculated as the peak versus mean of two baseline samples, there was a significant increase in the urinary excretion of $9 \alpha, 11 \beta-\mathrm{PGF}_{2} \quad(68.4 \pm 6.9$ versus $56.0 \pm 5.8 \mathrm{ng} \cdot \mathrm{mmol}$ creatinine $^{-1} ; \mathrm{p}<0.05$ ) (fig. $2 \mathrm{a}$ ). However, the magnitude of the increase in urinary excretion of $9 \alpha, 11 \beta$ $\mathrm{PGF}_{2}$ was less and the duration of the increased excretion was shorter than in the asthmatics, with values back to baseline at 60 min after challenge (fig. 3b).

There was also a significant increase in urinary $\mathrm{LTE}_{4}$ 

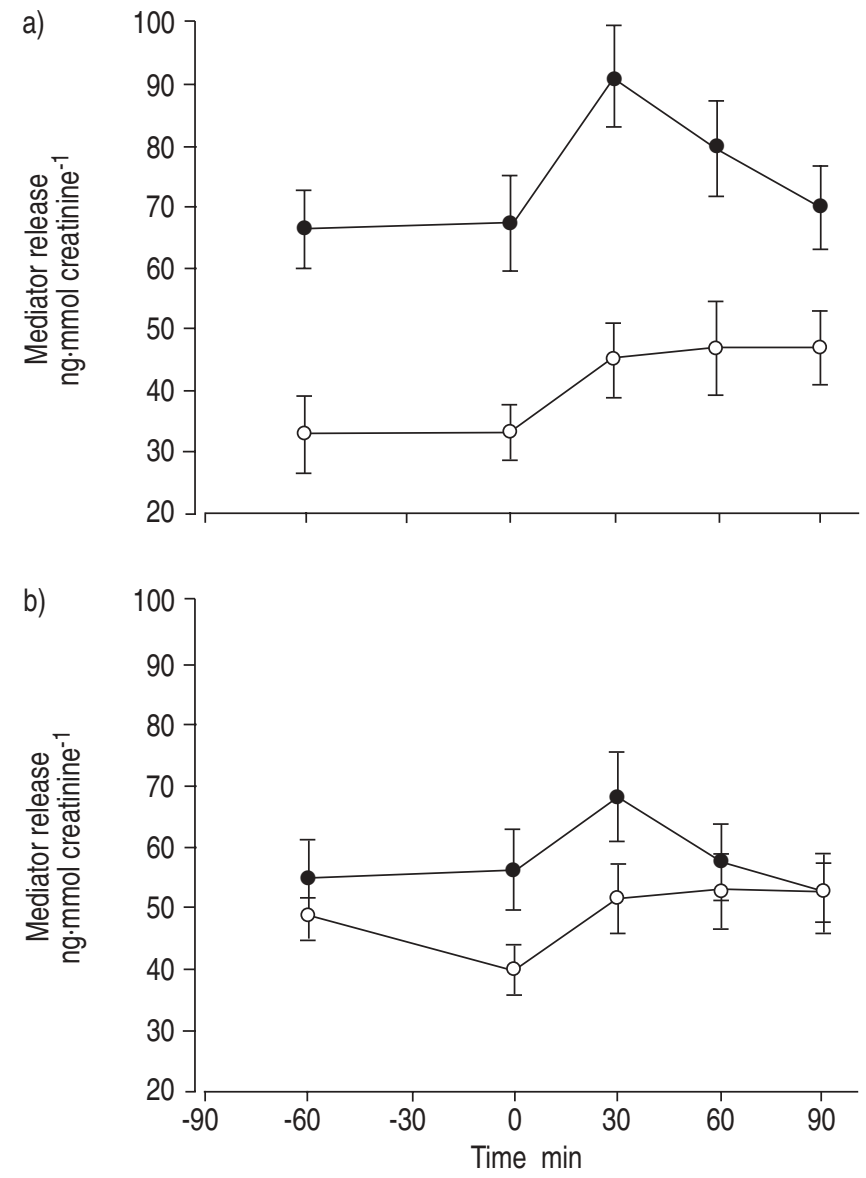

Fig. 3. -Mean \pm SEM urinary excretion of $9 \alpha, 11 \beta$-prostaglandin $F_{2}$ (O) and leukotriene $\mathrm{E}_{4}(\mathrm{O})$ in asthmatic subjects (a) and nonasthmatic subjects (b) over the $60 \mathrm{~min}$ collection period before and the 90 min period after the mannitol challenge.

$\left(58.5 \pm 5.3\right.$ versus $43.0 \pm 3.3 \mathrm{ng} \cdot \mathrm{mmol}$ creatinine $\left.^{-1} ; \mathrm{p}<0.01\right)$ (fig. 2b). The time-course for the urinary excretion of $\mathrm{LTE}_{4}$ was similar to the asthmatic subjects (fig. 3b).

There was a small but significant increase in the urinary excretion of $\mathrm{N}^{\tau}$-methylhistamine after challenge $(21.6 \pm 2.8$ versus $19.1 \pm 2.6 \mu \mathrm{g} \cdot \mathrm{mmol}$ creatinine ${ }^{-1}$; $\mathrm{p}<0.05$ ) (fig. $2 \mathrm{c}$ ).

\section{Asthmatics versus nonasthmatics}

There was no difference in the increase in $\mathrm{LTE}_{4}$ between nonasthmatic $\left(15.4 \pm 3.3 \mathrm{ng} \cdot \mathrm{mmol}\right.$ creatinine $\left.^{-1}\right)$ and asthmatic subjects $\left(18.4 \pm 6.0 \mathrm{ng} \cdot \mathrm{mmol}\right.$ creatinine $\left.^{-1} ; \mathrm{p}=0.68\right)$ (fig. 2b). However, in the nonasthmatics the change in $9 \alpha, 11 \beta-\mathrm{PGF}_{2}$ $\left(12.4 \pm 4.1 \mathrm{ng} \cdot \mathrm{mmol}\right.$ creatinine $\left.^{-1}\right)$ was significantly smaller compared to asthmatic subjects $(24.9 \pm 3.8 \mathrm{ng} \cdot \mathrm{mmol}$ creatinine ${ }^{-1} ; \mathrm{p}<0.05$ ) (fig. 2a). The changes in the levels of $\mathrm{N}^{\tau}$ methylhistamine after mannitol were not different between asthmatics $\left(2.6 \pm 1.5 \mu \mathrm{g} \cdot \mathrm{mmol}\right.$ creatinine $\left.\mathrm{e}^{-1}\right)$ and nonasthmatics $\left(2.5 \pm 0.8 \mu \mathrm{g} \cdot \mathrm{mmol}\right.$ creatinine $\left.^{-1} ; \mathrm{p}=0.93\right)$ (fig. $2 \mathrm{c}$ ).

Baseline levels of urinary mediators did not differ between the asthmatic and nonasthmatic group of subjects; $9 \alpha, 11 \beta$ $\mathrm{PGF}_{2}\left(66.9 \pm 6.6\right.$ versus $56.0 \pm 5.2 \mathrm{ng} \cdot \mathrm{mmol}$ creatinine $\left.{ }^{-1} ; \mathrm{p}=0.25\right)$, $\mathrm{LTE}_{4}\left(32.9 \pm 4.7\right.$ versus $43.0 \pm 3.3 \mathrm{ng} \cdot \mathrm{mmol}$ creatinine $\left.{ }^{-1} ; \mathrm{p}=0.12\right)$ and $\mathrm{N}^{\tau}$-methylhistamine $(18.2 \pm 2.2$ versus $19.1 \pm 2.6 \mu \mathrm{g} \cdot \mathrm{mmol}$ creatinine $^{-1} ; \mathrm{p}=0.80$ ) (fig. $\left.2 \mathrm{a}-\mathrm{c}\right)$.

\section{Discussion}

The results of this study demonstrate that the airway narrowing provoked by challenge with inhaled mannitol in asthmatic subjects is associated with increased urinary excretion of $9 \alpha, 11 \beta-\mathrm{PGF}_{2}$. The parent compound $\mathrm{PGD}_{2}$ is almost exclusively released by mast cells upon activation and is subsequently enzymatically converted to $9 \alpha, 11 \beta-\mathrm{PGF}_{2}$ in sites such as the lungs [7]. This compound is, in turn, excreted into the urine as a stable and dominating metabolite, and increased levels may be regarded as an index of mast cell activation [7]. Therefore, it is concluded that mannitol caused activation of mast cells in the airways of the asthmatics and this is probably a consequence of mannitol causing an increase in osmolarity of the airway surface liquid. Moreover, the increased excretion of the $\mathrm{PGD}_{2}$ metabolite may indicate an important role for $\mathrm{PGD}_{2}$ in the bronchoconstrictive response to mannitol. $\mathrm{PGD}_{2}$, as well as $9 \alpha, 11 \beta-\mathrm{PGF}_{2}$, are potent bronchoconstrictors in man [17], mainly acting on the TP-receptor $[18,19]$. Pretreatment with selective TP-receptor antagonists attenuated both $\mathrm{PGD}_{2}$ - and allergen-induced, but not histamine-induced, bronchoconstriction [20-22]. Release of $\mathrm{PGD}_{2}$ into the airways has been further documented after bronchial provocation with allergen [23]. Interaction between cys-LTs and $\mathrm{PGD}_{2}$ in provoking bronchoconstriction has also been indicated in asthmatic subjects [24].

The finding that the mannitol challenge only caused a minor change in urinary excretion of $\mathrm{N}^{\tau}$-methylhistamine may seem to contradict the conclusion about mast cell activation. However, the current authors have previously observed that urinary methylhistamine is a much less sensitive marker of mast cell activation in vivo. For example, following allergen challenge, the increase in $9 \alpha, 11 \beta-\mathrm{PGF}_{2}$ was much greater than that of methylhistamine [16]. Of particular interest to this study, is the previous finding that EIB was also associated with significantly increased urinary $9 \alpha, 11 \beta-\mathrm{PGF}_{2}$ $[6,7]$ at a time when only a nonsignificant trend for increased urinary $\mathrm{N}^{\tau}$-methylhistamine was found [6]. Mannitol is known to induce the release of histamine from lung mast cells in vitro [12]. Furthermore, the histamine antagonist, fexofenadine, is effective in reducing airway sensitivity to mannitol [14]. This suggests that preformed histamine is involved in the response to mannitol and its source is likely to be mast cells. Whilst basophils are also a source of histamine they do not synthesise $\mathrm{PGD}_{2}$ [25]. Nedocromil sodium inhibits the airway response to mannitol [26] and this effect is thought to occur by inhibiting or preventing the release of a variety of mast cell mediators [13]. The finding that there was no significant increase in urinary excretion of $\mathrm{N}^{\tau}$ methylhistamine in the asthmatic subjects suggest that the provoking stimulus in this group was insufficient to cause an increase in systemic histamine large enough to be reflected in urine.

It was also found that the mannitol-induced bronchoconstriction was associated with increased urinary $\mathrm{LTE}_{4}$ excretion. The finding is consistent with the previous demonstration that the LT antagonist montelukast inhibited the airway response to mannitol, as demonstrated by a faster recovery of the lung function to baseline after challenge [14]. Moreover, the observations add to the similarities with EIB, as it is well established that recovery of lung function to baseline after EIB is also much faster with antagonists of the cysteinyl-LT $[2,5,27,28]$. Measurements of urinary $\mathrm{LTE}_{4}$ have also demonstrated increased levels after $\operatorname{EIB}[4,5]$, although the magnitude is smaller and less consistent than after allergen-induced bronchoconstriction. As a technical note, it should be recognised that the time course of the bronchoconstriction after exercise and mannitol is short and 
this makes it very different to the prolonged airway responses that occur after allergen challenge. This may explain why it has been difficult to find significantly increased levels of urinary $\mathrm{LTE}_{4}$ after exercise in some studies [6]. It has been documented that the duration of exposure to a stimulus that causes bronchoconstriction determines the magnitude of overflow of $\mathrm{LTE}_{4}$ into the urine [29]. The similar profiles of mediator excretion into the urine after mannitol and exercise in asthmatics provide evidence for mast cell activation as a common mechanism for the airway narrowing.

An unexpected finding was that the inhalation of $635 \mathrm{mg}$ mannitol by the nonasthmatic subjects was also associated with a significant increase in levels of $\mathrm{LTE}_{4}$ and $9 \alpha, 11 \beta-\mathrm{PGF}_{2}$ and small changes in $\mathrm{N}^{\tau}$-methylhistamine. However, the cumulative dose of $635 \mathrm{mg}$ mannitol inhaled by the nonasthmatics was between one to 18 (median three)-times the dose inhaled by the asthmatics. Furthermore, with this stronger stimulus for mast cell activation, the increased urinary excretion of $9 \alpha, 11 \beta-\mathrm{PGF}_{2}$ in the nonasthmatic subjects was only about half that compared with the asthmatics and of shorter duration with levels back to baseline at $60 \mathrm{~min}$ after challenge. These findings suggest that the mast cells of the asthmatics were easier to activate or more numerous, or both. In keeping with this, a recent study reports that asthmatic subjects have significantly higher numbers of mast cells in the airways and a particularly higher proportion localised in the smooth muscle compared to nonasthmatic subjects [30]. In addition, eosinophils are more abundant in the airways of asthmatics with ongoing airway inflammation compared to nonasthmatics [30]. The cellular source of the LTs cannot be established in this study and although the mast cell is the most likely cell source, other cells, such as eosinophils, could have been involved.

As expected the nonasthmatic subjects did not have a reduction in FEV1 despite having significantly increased urinary levels of $\mathrm{LTE}_{4}$ and $9 \alpha, 11 \beta-\mathrm{PGF}_{2}$, which, as well as its parent compound $\mathrm{PGD}_{2}$, is a potent bronchoconstrictor [17]. The major difference between the response to inhaled mannitol in the two groups studied is most probably related to differences in airway responsiveness to the released mediators. It has been extensively documented that asthmatics have more sensitive airways than nonasthmatics and that airway narrowing would be expected to occur at low concentrations of these mediators [31]. A measurement of airway responsiveness to inhaled PGs or LTs was not part of this protocol, but hyperresponsiveness to $\mathrm{PGD}_{2}$, as well as $\mathrm{LTD}_{4}$, in asthmatics has been reported previously [32, 33]. Interestingly, in line with the present authors' hypothesis, it was documented that subjects presenting with EIB were hyperreactive to $\mathrm{PGD}_{2}$ [34].

From the findings presented here with mannitol challenge, it is suggested that the difference between asthmatic and nonasthmatic subjects is in the airway responsiveness to mediators of bronchoconstriction. This factor distinguishes the two groups more than differences in the degree of release of inflammatory mediators. This theory does not preclude the fact that there may also be differences with respect to the ease by which mediators can be released, but such discrepancies may be of comparatively less importance.

In conclusion, this study has documented that mannitol challenge is associated with mast cell activation and release of mediators of bronchoconstriction in asthmatic as well as in nonasthmatic subjects. This supports the proposal that increased osmolarity of the airway fluid lining is a general stimulus for activation of mast cells. Similar time courses of the urinary excretion of $9 \alpha, 11 \beta$-prostagladin $F_{2}$ were seen after exercise [6] and mannitol (present study). These findings lend further support to the concept that the stimulus and mechanism of airway narrowing to mannitol and exercise are similar $[8,9]$. The authors also conclude that mannitol causes bronchoconstriction only in the asthmatics, because only the asthmatic subjects display increased bronchial responsiveness to the liberated mediators. Future studies with combinations of different selective pharmacological interventions may further delineate the relative importance of the different mediators in causing the bronchoconstriction elicited by osmotic challenge. In particular, studies with agents blocking the biosynthesis or receptor-mediated action of prostglandin $\mathrm{D}_{2}$ are implicated based on the findings in the present study.

\begin{abstract}
Acknowledgements. The authors would like to thank B. Watson of the Dept of Molecular Genetics, RPA Hospital, Camperdown, Australia, for his help in storing the samples and C. Perry for her technical assistance in preparing the manuscript. They would also like to thank S-E. Dahlén for his helpful discussions in the design and analysis of the results. The use application for mannitol described in this study is covered by United States of America Patent No. 5,817,028 and internationally by PCT/AU95000086. The patent is owned by the Central Sydney Area Health Service and is licensed to Pharmaxis Pty Ltd NSW Australia.
\end{abstract}

\section{References}

1. Anderson SD, Daviskas E. The mechanism of exerciseinduced asthma is... J Allergy Clin Immunol 2000; 106: 453459.

2. Leff JA, Busse WW, Pearlman D, et al. Montelukast, a leukotriene-receptor antagonist, for the treatment of mild asthma and exercise-induced bronchoconstriction. $N$ Engl J Med 1998; 339: 147-152.

3. Kelly KD, Spooner CH, Rowe BH. Nedocromil sodium versus sodium cromoglycate in treatment of exercise-induced bronchoconstriction: a systematic review. Eur Respir J 2001; 17: 39-45.

4. Kikawa $\mathrm{Y}$, Miyanomae $\mathrm{T}$, Inoue $\mathrm{Y}$, et al. Urinary leukotriene E4 after exercise challenge in children with asthma. J Allergy Clin Immunol 1992; 89: 1111-1119.

5. Reiss TF, Hill JB, Harman E, et al. Increased urinary excretion of $\mathrm{LTE}_{4}$ after exercise and attenuation of exerciseinduced bronchospasm by montelukast, a cysteinyl leukotriene receptor antagonist. Thorax 1997; 52: 1030-1035.

6. O'Sullivan S, Roquet A, Dahlén B, et al. Evidence for mast cell activation during exercise-induced bronchoconstriction. Eur Respir J 1998; 12: 345-350.

7. Nagakura T, Obata T, Shichijo K, et al. GC/MS analysis of urinary excretion of $9 \alpha, 11 \beta-\mathrm{PGF}_{2}$ in acute and exerciseinduced asthma in children. Clin Exp Allergy 1998; 28: 181186.

8. Brannan JD, Koskela H, Anderson SD, Chew N. Responsiveness to mannitol in asthmatic subjects with exercise- and hyperventilation-induced asthma. Am J Respir Crit Care Med 1998; 158: 1120-1126.

9. Holzer K, Anderson SD, Chan H-K, Douglass J. Mannitol as a challenge test to identify exercise-induced bronchoconstriction in elite athletes. Am J Respir Crit Care Med 2003; 167: 534-547.

10. Anderson SD, Brannan J, Spring J, et al. A new method for bronchial-provocation testing in asthmatic subjects using a dry powder of mannitol. Am J Respir Crit Care Med 1997; 156: 758-765.

11. Eggleston PA, Kagey-Sobotka A, Schleimer RP, Lichtenstein LM. Interaction between hyperosmolar and IgEmediated histamine release from basophils and mast cells. Am Rev Respir Dis 1984; 130: 86-91.

12. Eggleston PA, Kagey-Sobotka A, Lichtenstein LM. 
A comparison of the osmotic activation of basophils and human lung mast cells. Am Rev Respir Dis 1987; 135: 10431048 .

13. Makhdum A, Pearce FL. Histamine release from mast cells and basophils. Agents Actions 1993; 38: C191-C193.

14. Brannan JD, Anderson SD, Gomes K, King GG, Chan H-K, Seale JP. Fexofenadine decreases sensitivity to and montelukast improves recovery from inhaled mannitol. $\mathrm{Am}$ J Respir Crit Care Med 2001; 163: 1420-1425.

15. Quanjer PH, Tammeling GJ, Cotes JE, Pedersen OF, Peslin $\mathrm{R}$, Yernault JC. Lung volumes and forced ventilatory flows. Eur Respir J 1993; 6: 5-40.

16. O'Sullivan S, Roquet A, Dahlén B, Dahlén S-E, Kumlin M. Urinary excretion of inflammatory mediators during allergen-induced early and late phase asthmatic reactions. Clin Exp Allergy 1998; 228: 1332-1339.

17. Beasley C, Robinson C, Featherstone R, et al. $9 \alpha, 11 \beta$ prostaglandin F2, a novel metabolite of prostaglandin D2 is a potent contractile agonist of human and guinea pig airways. J Clin Invest 1987; 79: 978-983.

18. Coleman RA, Sheldrick RL. Prostanoid-induced contraction of human bronchial smooth muscle is mediated by TPreceptors. Br J Pharmacol 1989; 96: 688-692.

19. Johnston SL, Freezer NJ, Ritter W, O'Toole S, Howarth $\mathrm{PH}$. Prostaglandin D2-induced bronchoconstriction is mediated only in part by the thromboxane prostanoid receptor. Eur Respir J 1995; 8: 411-415.

20. Beasley RC, Featherstone RL, Church MK, et al. Effect of a thromboxane receptor antagonist on $\mathrm{PGD}_{2-}$ and allergeninduced bronchoconstriction. J Appl Physiol 1989; 66: 16851693.

21. Johnston SL, Bardin PG, Harrison J, Ritter W, Joubert JR, Holgate ST. The effects of an oral thromboxane TP receptor antagonist BAY u 3405, on prostaglandin D2- and histamine-induced bronchoconstriction in asthma, and relationship to plasma drug concentrations. Br J Clin Pharmacol 1992; 34: 402-408.

22. al Jarad N, Hui KP, Barnes N. Effects of a thromboxane receptor antagonist on prostaglandin D2 and histamine induced bronchoconstriction in man. $\mathrm{Br} \mathrm{J}$ Clin Pharmacol 1994; 37: 97-100.
23. Murray JJ, Tonnel AB, Brash AR, et al. Prostaglandin D2 is released during acute allergic bronchospasm in man. Trans Assoc Am Physicians 1985; 98: 275-280.

24. Phillips GD, Holgate S. Interaction of inhaled LTC4 with histamine and PGD2 on airway caliber in asthma. $J$ Appl Physiol 1989; 66: 304-312.

25. O'Sullivan S. On the role of PGD2 metabolites as markers of mast cell activation in asthma. Acta Physiologica Scand 1999; 644: 1-74.

26. Brannan JD, Anderson SD, Freed R, Leuppi JD, Koskela H, Chan H-K. Nedocromil sodium inhibits responsiveness to inhaled mannitol in asthmatic subjects. Am J Respir Crit Care Med 2000; 161: 2096-2099.

27. Manning PJ, Watson RM, Margolskee DJ, Williams VC, Schwartz JI, O'Byrne PM. Inhibition of exercise-induced bronchoconstriction by MK-571, a potent leukotriene D4receptor antagonist. $N$ Engl J Med 1990; 323: 1736-1739.

28. Dahlén B, Roquet $\mathrm{A}$, Inman $\mathrm{MD}$, et al. Influence of zafirlukast and loratadine on exercise-induced bronchoconstriction. J Allergy Clin Immunol 2002; 109: 789-793.

29. Kumlin M, Dahlén B. The challenge procedure influences the extent of allergen-induced urinary excretion of leuotriene $\mathrm{E}_{4}$. Clin Exp Allergy 2000; 30: 585-589.

30. Brightling CE, Bradding P, Symon FA, Holgate ST, Wardlaw AJ, Pavord ID. Mast-cell infiltration of airway smooth muscle in asthma. N Engl J Med 2002; 346: 1699-1705.

31. Adelroth E, Morris MM, Hargreave FE, O'Byrne PM. Airway responsiveness to leukotrienes $\mathrm{C}_{4}$ and $\mathrm{D}_{4}$ and to methacholine in patients with asthma and normal controls. $N$ Engl J Med 1986; 315: 480-484.

32. Hardy CC, Robinson C, Tattersfield AE, Holgate ST. The bronchoconstrictor effect of inhaled prostaglandin D2 in normal and asthmatic men. N Engl J Med 1984; 311: 209213.

33. Davidson AB, Lee TH, Scanlon PD, et al. Bronchoconstrictor effects of leukotriene E4 in normal and asthmatic subjects. Am Rev Respir Dis 1987; 135: 333-337.

34. Nowak D, Templin K, Jorres R, Magnussen H. Comparison of airway responsiveness to prostaglandin D2 and histamine, methacholine or exercise in healthy and asthmatic subjects. Ann N Y Acad Sci 1991; 629: 442-445. 